\title{
Kick-Off Editorial for 2017: CNS Spectrums Is on the Move
}

\author{
Stephen M. Stahl
}

It has been 5 years since the transition of CNS Spectrums to Cambridge University Press and my editorship. What an exhilarating run it has been. Our impact factor has doubled twice, placing us in the upper tier of psychiatry journals as well as neurology journals now, with record numbers of downloads and citations year after year. We continue our association with the Neuroscience Education Institute, whose members get free full-text download access to the journal, whose poster presenters at the NEI Congress have their abstracts published as indexed and citable entries in the journal, and who sponsors and edits a

\section{TABLE 1. CNS Spectrums 2016 peer reviewers}

\begin{tabular}{ll} 
André Carvalho & Jean-Louis Millot \\
Andrea Cipriani & Jennifer O'Day \\
Andrea Fagiolini & José Menchón \\
Andrea Gaedigk & Joseph Goldberg \\
Andres Kanner & Katherine Burdick \\
Angel Montejo & Leonardo Fontenelle \\
Anna Comparelli & Leonardo Tondo \\
Antonio Barbosa & Loren Gianini \\
B. Mark Keegan & Luigi Janiri \\
Barbara Milrod & Marc Potenza \\
Bernhard Baune & Marco Mula \\
Bethany Brand & Mario Maj \\
Byron Creese & Mark Weiser \\
Carlos Blanco & Michael Ostacher \\
Charles Bowden & Michele Fornaro \\
Craig Nelson & Minoru Takeshima \\
Daniel Rosell & Mrigendra Das \\
Darin Dougherty & Neil Krishan Aggarwal \\
David Dunn & Norma Verdolini \\
David Goodman & Palmiero Monteleone \\
David Mischoulon & Paul Holtzheimer \\
Dina Popovic & Paulette Gillig \\
Domenico De Berardis & Philip Harvey \\
Dominique Drapier & Rajiv Tandon \\
Filho de Araújo & Rakesh Jain \\
Franco Mortara & Renato Alarcón \\
Gabriele Sani & Riccardo Degiorgi \\
Giulio Perugi & Richard Balon \\
Hal Wortzel & Veena Kumari \\
Helen Mayberg & Vita Dolzan \\
Howard Margolese & Wen-Jun Gao \\
Humberto Nicolini & Won-Myong Bahk \\
Jay Sapelkar & Yin Yao \\
\hline
\end{tabular}

special CME issue with multiple articles every year. Those activities will continue moving forward as well.

As always, we rely on a fantastic group of field editors (Joe Goldberg, Carlos Zarate, Frank Tarazi, Tom Schwartz, and Thomas Schlaepfer) working with a wonderful editorial board and many, many reviewers who are incredibly generous with their time. A list of 2016 reviewers for CNS Spectrums is attached as Table 1, and with our great thanks. Our authors are nothing short of stellar, and our journal is now accessible to major medical libraries and institutions throughout the world. In September, the journal transitioned to the new online platform, "Cambridge Core," which will provide our readers with an improved experience. Our senior editor Ann Avouris and our managing editor Lisa Arrington keep things at CNS Spectrums ticking like a clock and provide invaluable management and ideas to keep us moving forward.

So, what will change moving forward, and what will keep CNS Spectrums on the move? I have outlined some of our plans in Table 2 . To begin, we will be rotating some

\section{TABLE 2. CNS Spectrums on the move}

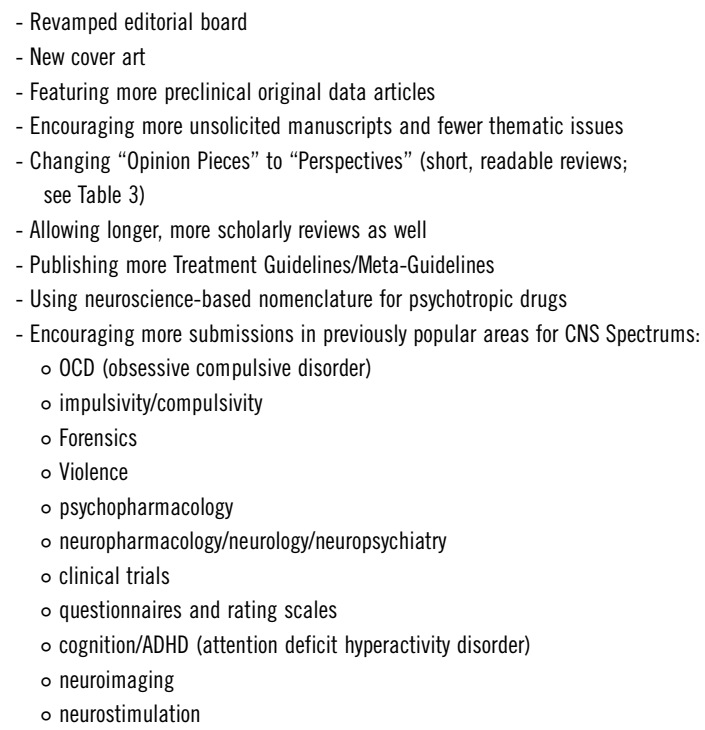


TABLE 3. Summary of article types and requirements

\begin{tabular}{|c|c|c|c|c|}
\hline Article type & Length & Abstract & Figures/ Tables & Purpose/ features \\
\hline Original research & $\begin{array}{l}6,000 \text { words Up to } 100 \\
\text { references }\end{array}$ & $\begin{array}{l}\text { Structured }<250 \text { words } \\
\quad \text { No citations }\end{array}$ & $\begin{array}{l}\text { Minimum } 2 \text { tables and/or } \\
\text { figures }\end{array}$ & $\begin{array}{l}\text { Original Research: Reports the results of a formal study based on } \\
\text { original research. Structured abstract }\end{array}$ \\
\hline Review article & № limit & $\begin{array}{l}\text { Unstructured }<250 \\
\quad \text { words No citations }\end{array}$ & $\begin{array}{l}\text { Minimum } 2 \text { tables and/or } \\
\text { figures Maximum } 6 \text { tables } \\
\text { and/or figures }\end{array}$ & $\begin{array}{l}\text { Review: Written as a literature review of an established topic, as } \\
\text { suggested by its name. Clinical Implication points }\end{array}$ \\
\hline Perspectives & $\begin{array}{l}3,000 \text { words } 30-60 \\
\text { references }\end{array}$ & $\begin{array}{l}\text { Unstructured }<150 \\
\quad \text { words No citations }\end{array}$ & $\begin{array}{l}\text { Minimum } 2 \text { tables and/or } \\
\text { figures Maximum } 6 \text { tables } \\
\text { and/or figures }\end{array}$ & $\begin{array}{l}\text { Perspective: A type of review that is a short, focused summary of } \\
\text { a single recent advance, a sort of spotlight on the topic, } \\
\text { which could be for example a single point hypothesis or a } \\
\text { novel model. It can stimulate debate and new research. }\end{array}$ \\
\hline Meta guidelines & 6,000 words & $\begin{array}{l}\text { Unstructured }<250 \\
\quad \text { words No citations }\end{array}$ & $15-25$ tables and/or figures & $\begin{array}{l}\text { Meta guidelines: A meta-guideline. Is a "guideline of guidelines" } \\
\text { put together by several leading figures in a field in which } \\
\text { there are multiple competing guidelines that require } \\
\text { synthesis and updating. Outlines diagnostic and treatment } \\
\text { options and medications; Includes an abstract, introduction, } \\
\text { and optional additional text. }\end{array}$ \\
\hline Editorial & $900-1,500$ words & Unstructured 150 words & $\begin{array}{l}1 \text { table or } 1 \text { figure (excluding } \\
\text { invited guest editorials for } \\
\text { thematic Issues) }\end{array}$ & $\begin{array}{l}\text { Editorial: Introduces a new Idea or a particular theme, usually } \\
\text { written by the editor-in-chief and occasionally submitted by a } \\
\text { guest editor. A luminary In the field might also be approached } \\
\text { to provide a guest editorial. }\end{array}$ \\
\hline
\end{tabular}

of our editorial board, with some new blood coming on board, and with some retirements to keep things fresh, and these announcements will be coming soon. We will also be featuring new cover art starting in 2017, and some changes to the formats of articles we accept (see Table 3 ). We especially continue to encourage original articles of new data, increasingly featuring preclinical studies of translational value as well as clinical studies, especially in popular areas already being published extensively in $C N S$ Spectrums (see Table 2). For example, in the pipeline for
2017 are some very notable thematic issues including one on "Depression with Mixed Features," another on "Psychiatry and Terrorism," and yet another showcasing our second special issue on "Neuropsychiatry."

Hopefully, this kick-off editorial will help answer the question, "What is CNS Spectrums?" and will demonstrate that our journal is certainly on the move. I look forward to the exciting developments in store for us, and invite you all to submit your important work to our journal. 